\title{
ANALISIS KETAHANAN HIDUP PASIEN PENYAKIT GINJAL KRONIS DENGAN HEMODIALISIS DI RSUD Dr. SOETOMO SURABAYA
}

\author{
Dony Yulianto", Hari Basuki Notobroto", Widodo ${ }^{* *}$ \\ *Departemen Biostatistika Fakultas Kesehatan Masyarakat Universitas Airlangga \\ ${ }^{* *}$ Instalasi Hemodialisis RSUD Dr. Soetomo Surabaya \\ Dony Yulianto \\ Email : donyyulianto679@gmail.com
}

\begin{abstract}
ABSTRAK
Keterbatasan waktu dan biaya dalam penelitian menyebabkan data yang diperoleh tidak lengkap (data tersensor). Menganalisis data tersensor dapat menggunakan analisis khusus yaitu analisis survival. Penelitian ini dilakukan untuk menganalisis angka ketahanan hidup dan melihat adanya perbedaan antar kategori pada setiap variabel pada pasien PGK yang menjalani Hemodialisis di RSUD Dr. Soetomo.

Penelitian dilakukan dengan mengambil data sekunder di Rekam Medik Instalasi Hemodialisis RSUD Dr. Soetomo. Data yang diambil meliputi data pasien PGK yang mulai menjalani HD pada periode 2010-2013 dengan melihat karakteristik jenis kelamin, usia, riwayat Hipertensi, Diabetes Melitus, frekuensi HD dan adanya komplikasi Anemia. Analisis yang digunakan adalah uji Kaplan Meier dan Log Rank.

Rata-rata ketahanan hidup pasien PGK dengan HD secara umum adalah 67,84 bulan. Pasien dengan jenis kelamin perempuan, pada rentang usia 46-65 tahun, frekuensi HD $\geq 3$ kali, dan memiliki riwayat Hipertensi, Diabetes Melitus serta adanya komplikasi anemia memiliki rata-rata ketahanan hidup lebih rendah. Analisis uji Log Rank menunjukkan bahwa adanya perbedaan signifikan antar kategori dalam satu variabel bebas pada kurva survival (pvalue $<0,05)$. Variabel usia pasien $(\mathrm{p}=0,022)$, riwayat Hipertensi $(\mathrm{p}=0,020)$ dan riwayat Diabetes Melitus ( $\mathrm{p}=0,0355)$ diketahui memiliki perbedaan signifikan antar kategorinya.

Kesimpulan yang dapat ditarik adalah pasien PGK yang menjalani HD di RSUD Dr. Soetomo dengan rentang usia 46-65 tahun, terdapat riwayat penyakit Hipertensi dan Diabetes Melitus memiliki rata-rata ketahanan hidup lebih rendah dibandingkan dengan pasien yang berusia antara 26-45 tahun, dan tidak memiliki riwayat penyakit keduanya.
\end{abstract}

Kata Kunci : Ketahanan Hidup, Kaplan Meier, Hemodialisis

\section{ABSTRACT}

Limited time and budgets in research makes the obtainable data are not very comprehensive (censored data). Thus, making the researcher to use a peculiar analysis technique, whic is survival analysis. The goals of this research were to analyze the survival rate and to see the differences on each variables in Chronic Kidney Disease's (CKD) patient that going through hemodialysis therapy in Dr. Soetomo Hosiptal.

The study was conducted by taking secondary data in Medical Record of Instalation of Hemodialysis in Dr. Soetomo Hospital. The data retrieved include data of CKD patients who began their Hemodialysis in the period of 2010-2013 by looking at the characteristics of sex, age, history of hypertension, Diabetes Melitus, Frequency of Hemodialysis and presence of complications Anemia. The analysis used was the Kaplan Meier and Log Rank Test.

The survival rate of CKD patients with Hemodialysis in general was 67.84 months. Female patients, age between 46-65 years, frequency of HD therapy $\geq 3$ times, had a history of hypertension and Diabetes Melitus and had a complications of anemia have a lower 
survival rate. Variable age of patients $(p=0.022)$, history of hypertension $(p=0.020)$ and a history of Diabetes Melitus ( $p=0.0355)$ is known to have significant differencesof survival time between categories.

The conclusion that can be drawn is that CKD patients Hemodialysis in Dr. Soetomo Hospital with age range 46-65 years, had a history of hypertension and Diabetes Melitus have lower survival rate compared to patients aged between 26-45 years, and had no history of both.

Keywords: Survival Rate, Kaplan Meier, Hemodialysis

\section{PENDAHULUAN}

Penyakit Ginjal Kronis (PGK) adalah adanya kelainan struktur ginjal atau penurunan fungsi ginjal secara progresif dan irreversible. Penyakit Ginjal Kronis ditandai dengan adanya penurunan GFR (Glomerulus Filtration Rate) $<60$ $\mathrm{ml} / \mathrm{menit} / 1,73 \mathrm{~m}^{2}>3$ bulan dengan atau tanpa kerusakan ginjal. Dalam kurun waktu 1999-2012, prevalensi Penyakit Ginjal Kronis mengalami peningkatan hingga 40\%. Indonesia sendiri termasuk negara dengan tingkat penderita gagal ginjal cukup tinggi, sebanyak 83\% pasien yang melakukan Hemodialisis adalah pasien dengan penyakit Gagal Ginjal Terminal.

Hemodialisis sendiri adalah salah satu jenis terapi pengganti ginjal yang paling banyak dilakukan oleh pasien Penyakit Ginjal Kronis. PGK dibagi menjadi 5 stadium di mana stadium terakhir atau ke $\mathrm{V}$ merupakan stadium yang paling buruk. Pada stadium tersebut, ginjal sudah tidak berfungsi secara maksimal sehingga membutuhkan terapi pengganti ginjal, salah satunya Hemodialisis. Jenis pelayanan pada renal unit di Indonesia paling banyak adalah melayani Hemodialisis (78\%) pada tahun 2012.

Hemodialisis merupakan salah satu terapi pengganti ginjal buatan dengan tujuan untuk mengeliminasi sisa-sisa produk metabolisme (protein) dan koreksi gangguan keseimbangan cairan dan elektrolit antara kompartemen darah dan dialisat melalui selaput membran semipermiabel yang berperan sebagai ginjal buatan (dialiser). Di Indonesia, setiap tahun angka pasien baru HD meningkat. Seperti pada tahun 2012, angka pasien baru HD menjadi 19.621 pasien. Angka ini meningkat 27\% dibandingkan pada tahun 2011. Hal ini membuktikan selain pasien PGK yang meningkat, pasien HD juga ikut meningkat tiap tahunnya.

Pasien menjalani Hemodialisis mempunyai angka kematian yang sangat tinggi dibandingkan dengan populasi umum. Angka kematian pada tahun pertama dialisis di tahun 2004 adalah 24,5\% di mana 17\% lebih tinggi dibanding pada tahun kedua dan seterusnya. Menurut penelitian oleh Rolim dkk di tahun 2014, survival rate pasien PGK yang menjalani Hemodialisis sebesar $84,41 \%$ pada satu tahun dan 63,32\% pada lima tahun. Angka 
kematian karena Hemodialisis ini bukan murni penyebabnya adalah Hemodialisis namun banyak faktor yang diduga mempengaruhinya. Faktor-faktor tersebut adalah Hipertensi dan Diabetes Melitus. Menurut penelitian yang dilakukan oleh Mousavie dkk di tahun 2010, menyatakan bahwa faktor-faktor yang berpengaruh terhadap ketahanan hidup pasien Penyakit Ginjal Kronis antara lain usia, status nutrisi, adekuasi Hemodialisis, metode terapi pengganti ginjal dan etiologi gagal ginjal. Menurut penelitian oleh Valdivia dkk pada tahun 2013, faktor yang berpengaruh menurunkan survival rate pasien Hemodialisis adalah Hipertensi, inadekuat akses vaskular dan Diabetes Melitus, sedangkan pasien dengan usia >60 tahun, malnutrisi, mengalami hypoal buminemia, anemia dan adanya penyakit kardiovaskuler memiliki rata-rata ketahanan hidup yang rendah.

Berdasarkan kedua pernyataan di atas, dapat ditarik kesimpulan kecil bahwa etiologi penyakit PGK seperti Hipertensi dan Diabetes Melitus memiliki peran besar untuk mempengaruhi perubahan survival rate pasien PGK yang menjalani HD. Dapat diketahui bahwa tiga etiologi PGK tertinggi di tahun 2010 adalah Hipertensi (5.564), Diabetes Melitus (4.199) dan Glomerulonefritis (1.966). Hal ini dapat mempertajam keinginan peneliti untuk menganalisis ketahanan hidup dengan menggunakan karakteristik etiologi tersebut.
Dengan adanya informasi mengenai ketahanan hidup pasien PGK yang menjalani HD tersebut, peneliti ingin menganalisis ketahanan hidup pasien PGK yang menjalani HD di salah satu rumah sakit rujukan utama di Indonesia Timur. Rumah sakit ini merupakan rumah sakit kelas A dan terbesar di provinsi Jawa Timur. Tidak salah apabila banyak pasien HD yang melakukan terapi di rumah sakit ini. Peneliti ingin melihat ketahanan hidup pasien baik secara umum maupun berdasarkan karakteristik-karakteristik sesuai dengan latar belakang penelitian yang telah dijelaskan sebelumnya dengan menggunakan analisis survival.

Analisis survival adalah metode yang berhubungan dengan waktu, mulai dari awal pengamatan seperti halnya pasien masuk rumah sakit, pasien menjalani terapi atau pasien didiagnosa suatu penyakit hingga terjadinya suatu kejadian yang diinginkan oleh peneliti seperti kambuhnya penyakit, sembuh atau kematian. Dalam perjalanannya, peneliti dapat dipastikan akan menemukan banyak hambatan seperti waktu, biaya dan hambatan dari subjek itu sendiri. Hambatan tersebut akan berdampak pada data yang diperoleh. Data akan tidak lengkap. Data yang tidak lengkap tersebut dinamakan data tersensor. Analisis yang cocok untuk mengolah data tersensor adalah analisis survival.

Salah satu metode dalam analisis survival yang paling sederhana dan mudah 
dilakukan adalah Kaplan Meier. Metode ini tidak membutuhkan data yang terlalu banyak. Metode ini merupakan metode deskriptif, yang hanya menggambarkan kurva survival. Dalam melakukan analisis data survival, selain dengan analisis secara deskriptif juga harus dilakukan secara statistik, karena perbedaan yang tampak secara deskriptif belum tentu bermakna secara deskriptif. Maka dari itu, uji statistik yang digunakan adalah uji Log Rank. Dengan menggunakan uji Log Rank, dapat diketahui adanya perbedaan antar kategori dalam setiap faktor atau variabel. Dengan diketahui adanya perbedaan, maka hasil tersebut dapat digunakan oleh pihak instansi terkait untuk melaksanakan sebuah evaluasi program atau perencanaan program terbaru guna meningkatkan ketahanan hidup pasien.

\section{METODE PENELITIAN}

Penelitian ini merupakan jenis penelitian observasional analitik. Peneliti tidak memberikan perlakuan apapun terhadap subjek atau responden, hanya melakukan pengambilan data sekunder dan melakukan uji statistik pada data tersebut. Penelitian ini juga termasuk penelitian terapan dengan konsep kohort retrospektif.

Penelitian dilakukan di Rekam Medik Instalasi Hemodialisis RSUD Dr. Soetomo Surabaya selama lima bulan (Maret-Juli) mulai dari perijinan, uji kelayakan etik hingga proses pengambilan data.
Populasi penelitian ini adalah seluruh pasien yang menjalani Hemodialisis pada periode 2010-2013. Sampel penelitian adalah seluruh pasien yang mulai menjalani Hemodialisis pada periode 2010-2013 yang memenuhi 6 (enam) karakteristik yaitu usia, jenis kelamin, riwayat penyakit Hipertensi dan Diabetes Melitus, frekuensi HD dan komplikasi Anemia.

Data yang terkumpul diperiksa kembali, kemudian dianalisis dengan menggunakan IBM SPSS Statistic 21.

\section{HASIL PENELITIAN}

Berdasarkan penelitian yang dilakukan, diperoleh 82 data pasien Penyakit Ginjal Kronis yang mulai menjalani terapi Hemodialisis pada periode 2010-2013. Pada 82 data tersebut, 70 data pasien merupakan data survival tersensor dan 12 data pasien merupakan data survival tidak tersensor atau mengalami event. Penyebab data tersensor dan tidak tersensor, dapat dijelaskan pada tabel 1 berikut ini.

Tabel 1. Distribusi Status Data Pasien PGK dengan Hemodialisis

\begin{tabular}{lcc}
\hline Status Pasien & n & $\mathbf{\%}$ \\
\hline Tersensor & & \\
\hline Aktif HD & 68 & 82,9 \\
Pindah HD & 2 & 2,4 \\
\hline Tidak Tersensor & & \\
\hline Meninggal & 12 & 14,6 \\
Dunia & & \\
Total (\%) & $\mathbf{8 2}$ & $\mathbf{1 0 0}$ \\
\hline
\end{tabular}




\section{Distribusi Pasien}

Berdasarkan gambar 1 di bawah ini, distribusi data pasien berdasarkan karakteristik usia terlihat bahwa sebagian besar pasien PGK yang mulai menjalani HD pada periode 2010 - 2013 adalah pasien dengan rentang usia 26-45 tahun (37). Kemudian diikuti oleh pasien dengan rentang usia 46-65 tahun (35) yang memiliki selisih sangat kecil. Rata-rata usia pasien 44 tahun.

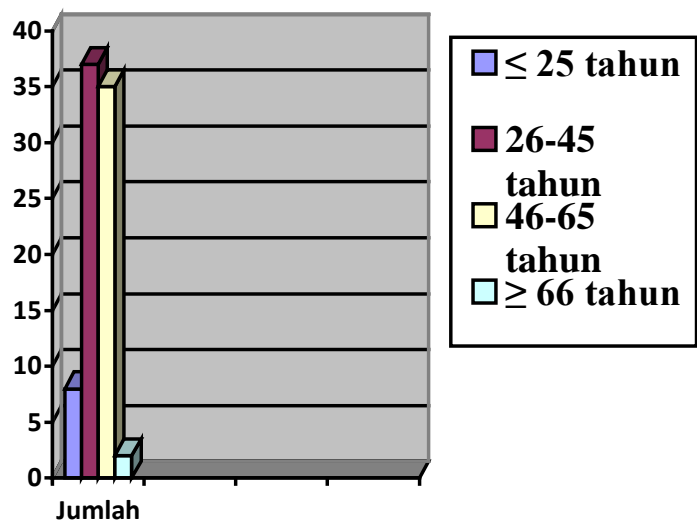

Gambar 1. Distribusi data pasien berdasarkan usia.

Dari 82 data pasien yang diperoleh, sebagian besar pasien berjenis kelamin laki-laki. Pasien dengan jenis kelamin lakilaki sebanyak 54,9\%, sedangkan pasien dengan jenis kelamin perempuan sebanyak 37 pasien atau $45,1 \%$.

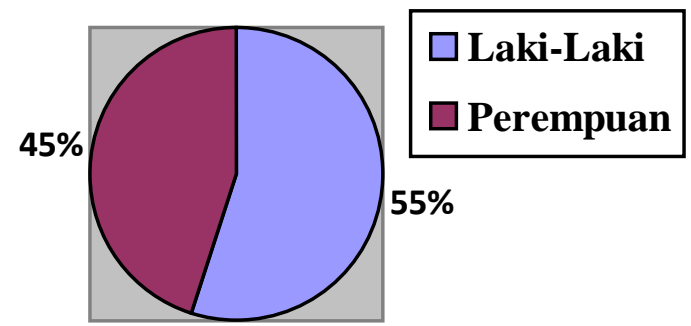

Gambar 2. Distribusi data pasien berdasarkan jenis kelamin

Berdasarkan distribusi klinis pada tabel 2, pasien PGK yang menjalani Hemodialisis sebagian besar memiliki riwayat Hipertensi dan mempunyai komplikasi Anemia. Pasien dengan riwayat Hipertensi sebanyak 64 pasien, sedangkan pasien yang mempunyai riwayat Diabetes Melitus sebanyak 23 pasien. Pasien dengan komplikasi anemia juga lebih banyak jika dibandingkan dengan yang tidak, yaitu sebanyak 48 pasien.

Tabel 2. Distribusi klinis pasien PGK dengan Hemodialisis.

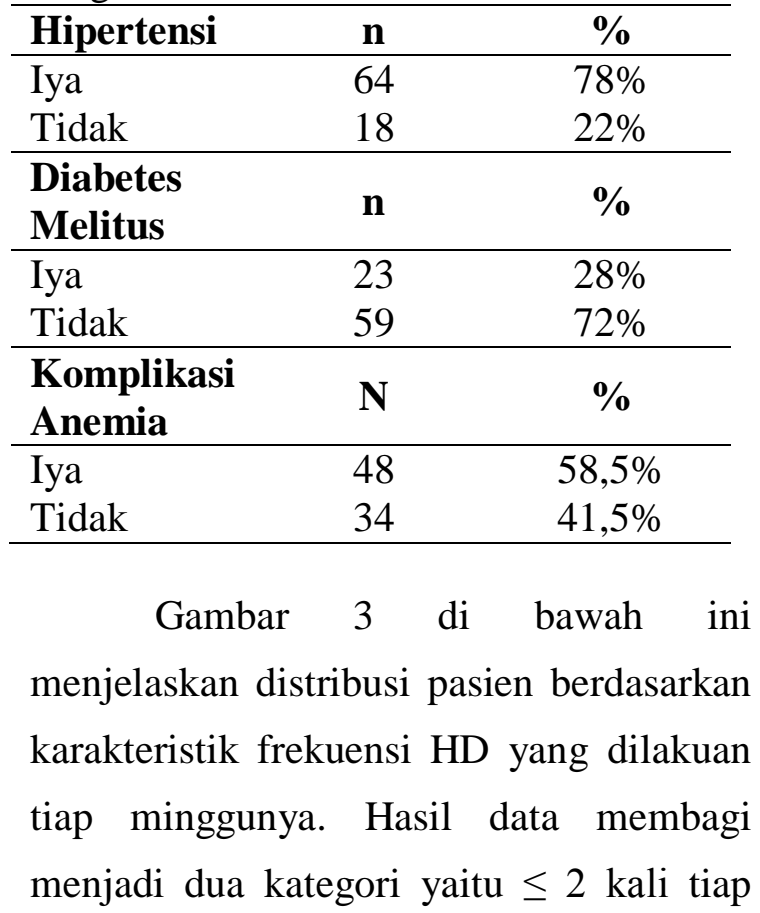


minggu dan $\geq 3$ kali tiap minggu. Pasien yang menjalani Hemodialisis sebanyak $\leq 2$ kali tiap minggu memiliki jumlah lebih banyak dibandingkan dengan pasien yang menjalani Hemodialisis sebanyak $\geq 3$ kali tiap minggu, yakni 89\%, sedangkan 11\% adalah pasien dengan frekuensi terapi Hemodialisis sebanyak $\geq 3$ kali tiap minggu.

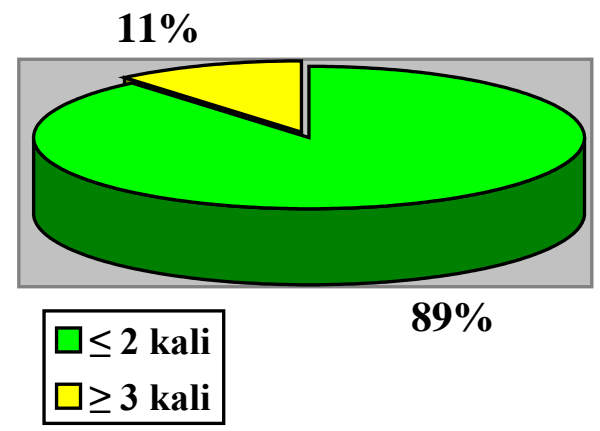

Gambar 3. Distribusi data pasien berdasarkan frekuensi Hemodialisis.

\section{Kurva Survival}

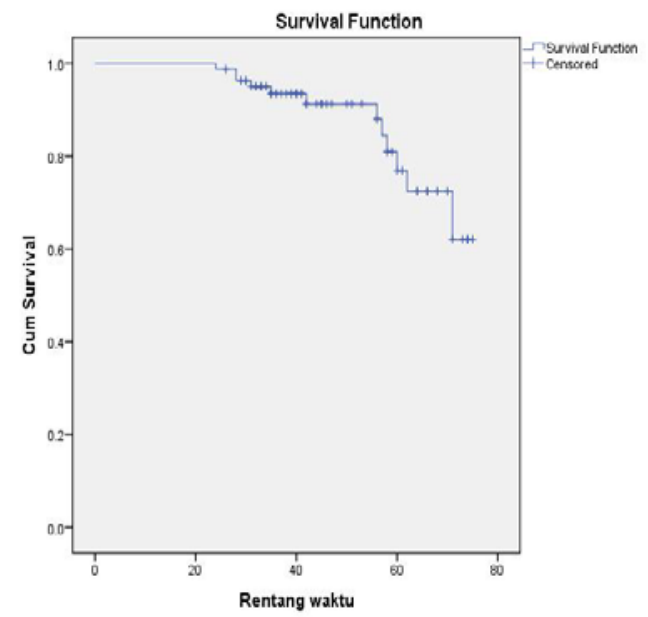

Gambar 4. Kurva survival secara umum

Berdasarkan gambar 5 semakin bertambah bulan, kurva semakin menurun. Hal itu berarti bahwa ketahanan hidup pasien PGK dengan Hemodialisis semakin menurun seiring dengan bertambahnya waktu. Pada gambar, tampak bahwa terjadi lima event pada 40 bulan pertama (ditandai dengan adanya garis yang jatuh). Rata-rata ketahanan hidup pasien Penyakit Ginjal Kronis yang menjalani Hemodialisis di RSUD Dr. Soetomo Surabaya adalah 67,84 bulan.

Tabel 3. Uji Log Rank karakteristik pasien PGK dengan Hemodialisis

\begin{tabular}{llc}
\hline No & \multicolumn{1}{c}{ Karakteristik } & P \\
\hline 1. & Usia Pasien & 0,022 \\
2. & Jenis Kelamin & 0,458 \\
3. & Riwayat Hipertensi & 0,020 \\
4. & Riwayat Diabetes & 0,0355 \\
& Melitus & \\
5. & Frekuensi & 0,826 \\
& Hemodialisis & 0,466 \\
\hline
\end{tabular}

Berdasarkan tabel 3 di atas, dari 6 karakteristik yang ada, riwayat Hipertensi, riwayat Diabetes Melitus dan usia pasien signifikan memiliki perbedaan ketahanan hidup pada kategorinya masing-masing.

Rata-rata ketahanan hidup pasien dengan rentang usai 26-45 tahun adalah 70 bulan, sedangkan pada usia 46-65 tahun lebih rendah yakni 61 bulan. Untuk kategori lainnya yakni $\leq 25$ tahun dan $\geq 66$ tahun, tidak dapat diketahui rata-rata ketahanan hidupnya karena 100\% data pada kategoru tersebut tersensor.

Berdasarkan angka tersebut, dapat dinyatakan bahwa rata-rata ketahanan hidup pasien dengan rentang usia 46-65 tahun lebih rendah dibandingkan dengan 
usia 26-45 tahun. Hal ini juga sesuai dengan hasil uji Log Rank pada tabel 3, di mana karakteristik usia merupakan karakteristik yang signifikan terdapat perbedaan. Berdasarkan uji Log Rank, ketahanan hidup pasien PGK dengan Hemodialisis usia 46-65 tahun lebih rendah dari pada usia 26-45 tahun.

Pada gambar 5, garis kuning merupakan garis survival pasien usia 4665 tahun. Garis kuning merupakan garis yang paling bawah, itu memiliki maksud bahwa usia tersebut memiliki ketahanan hidup paling rendah dibanding kategori usia lainnya.

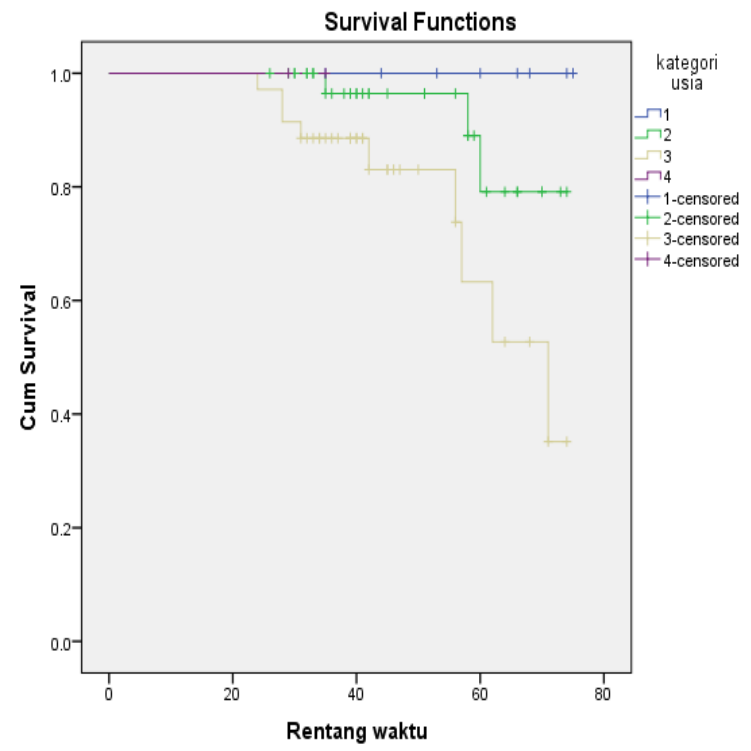

Gambar 5. Kurva survival berdasarkan karakteristik usia.

Pada karakteristik jenis kelamin tidak didapatkan perbedaan signifikan di mana pasien laki-laki ketahanan hidupnya tidak berbeda dengan pasien perempuan (lihat tabel 3). Selain itu, tidak adanya perbedaan signifikan juga terluhat pada kurva survivalnya yang terdapat garis saling silang. Rata-rata ketahanan hidup pasien laki-laki lebih tinggi yaitu 68,84 bulan, sedangkan pada perempuan 66,29 bulan.

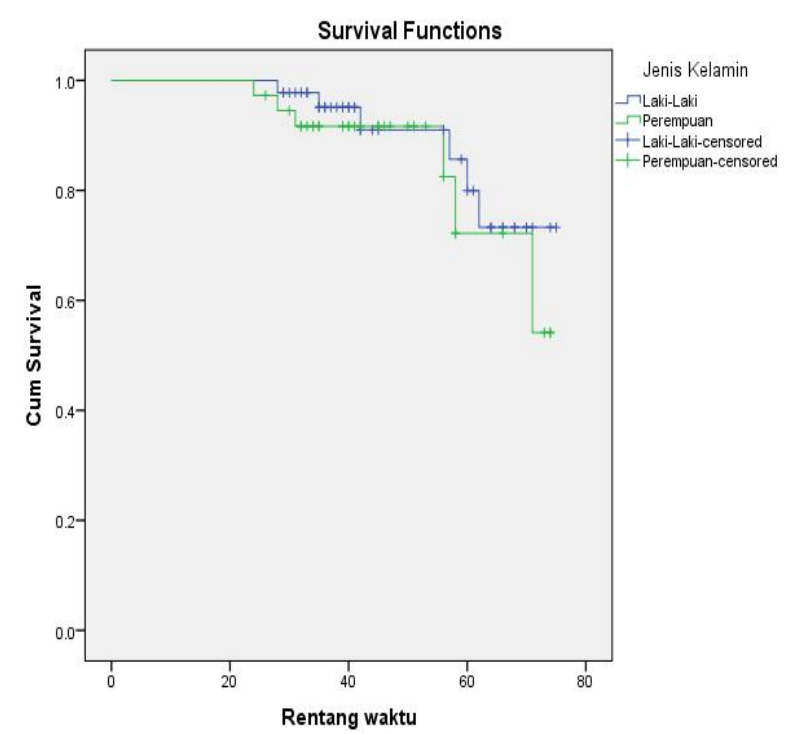

Gambar 6. Kurva survival pasien berdasarkan jenis kelamin.

Adanya riwayat Hipertensi ternyata berdasarkan hasil uji Log Rank memiliki perbedaan yang signifikan. Pasien PGK yang menjalani Hemodialisis yang memiliki riwayat Hipertensi ketahanan hidupnya lebih rendah jika dibandingkan dengan yang tidak memiliki riwayat penyakit tersebut.

Selain itu, rata-rata ketahanan hidup pasien tersebut juga lebih rendah dibandingkan dengan yang tidak ada riwayat Hipertensi. Berdasarkan kurva survival, garis pasien dengan riwayat Hipertensi lebih jatuh ke bawah (lihat gambar 7). Rata- rata ketahanan hidup 
pasien yang memiliki riwayat Hipertensi adalah 64,35 bulan.

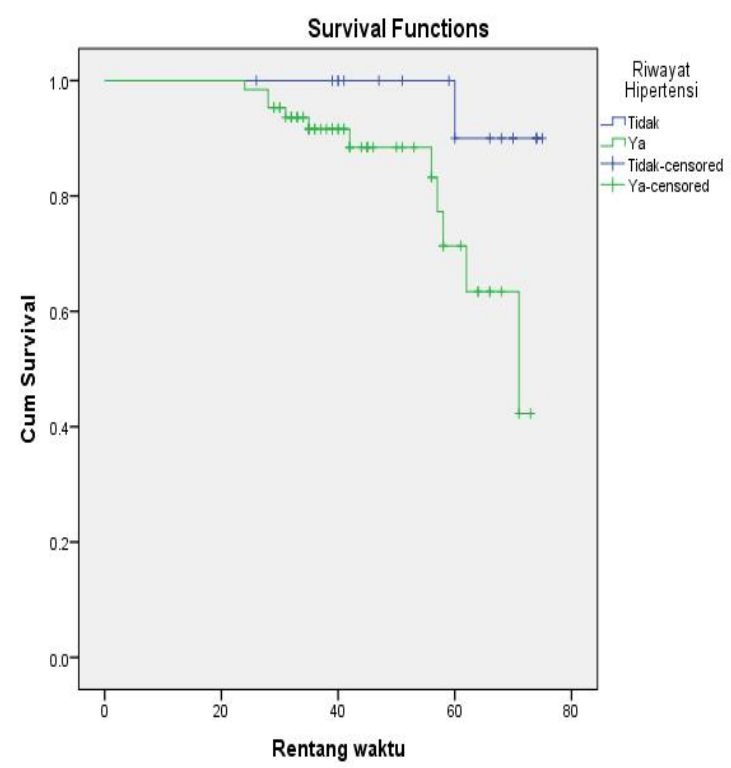

Gambar 7. Kurva survival pasien berdasarkan riwayat Hipertensi

Selain riwayat Hipertensi, riwayat

Diabetes Melitus juga terdapat perbedaan yang signifikan. Ketahanan hidup pasien PGK yang menjalani Hemodialisis dan mempunyai riwayat Diabetes Melitus lebih rendah dari pada pasien yang tidak memiliki riwayat penyakit tersebut. Ratarata ketahanan hidup pasien yang memiliki riwayat DM adalah 60,87 bulan, sedangkan yang tidak memiliki adalah 69,73 bulan. Hal ini tergambar jelas di kurva survival pada gambar 8 di mana garis yang paling jatuh ke bawah adalah garis pasien dengan riwayat DM.

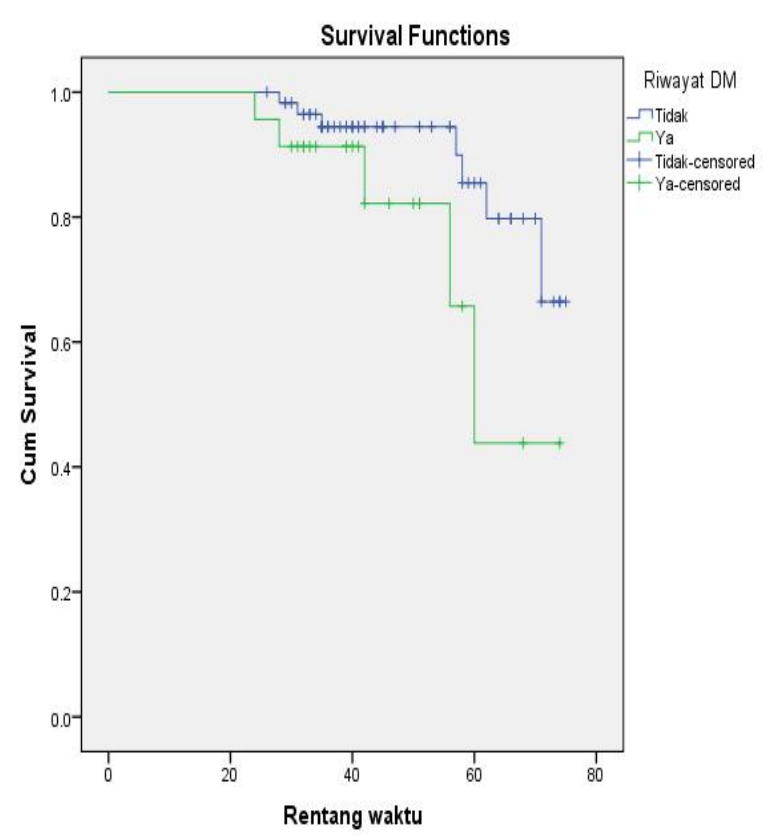

Gambar 8. Kurva survival pasien berdasarkan riwayat Diabetes Melitus. Frekuensi Hemodialisis berdasarkan hasil uji Log Rank tidak memiliki perbedaan signifikan. Hal tersebut berarti ketahanan hidup pasien dengan frekuensi $\mathrm{HD} \leq 2$ kali tiap minggu tidak berbeda dengan frekuensi $\geq 3$ kali tiap minggu. Namun, rata-rata ketahanan hidup pasien dengan frekuensi HD $\leq 2$ kali tiap minggu lebih tinggi dari pada frekuensi $\mathrm{HD} \geq 3$ kali tiap minggu, yakni 67,66 bulan. Pada gambar 9 di bawah ini, garis biru merupakan garis frekuensi $\leq 2$ kali tiap minggu. Garis biru jatuh lebih banyak karena memang terjadi banyak kejadian meninggal dunia, namun rata-rata ketahanan hidupnya masih tinggi jika dibandingkan dengan frekuensi $\geq 3$ kali tiap minggu. 


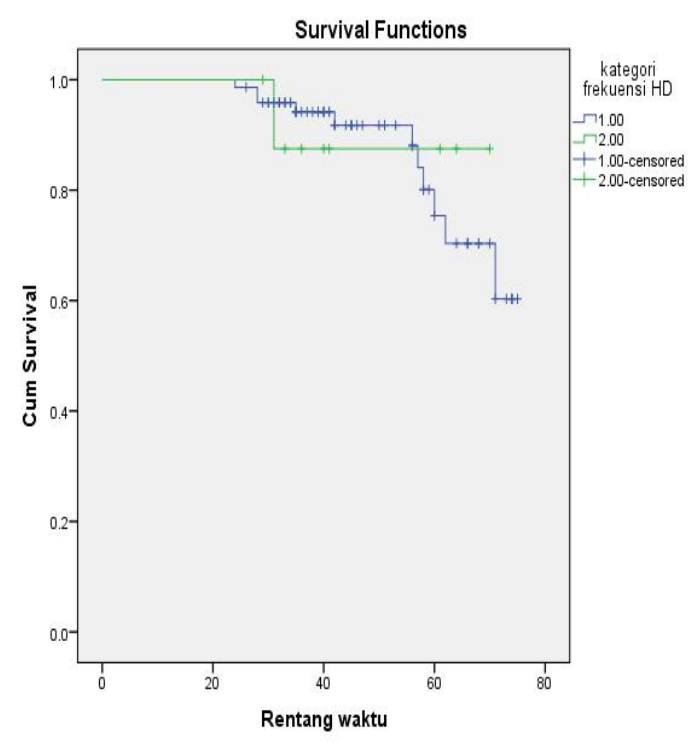

Gambar 9. Kurva survival pasien berdasarkan frekuensi Hemodialisis.

Komplikasi anemia juga tidak dapat diketahui perbedaanya secara signifikan. Pasien dengan komplikasi anemia angka ketahanan hidupnya tidak berbeda dengan pasien yang tidak memiliki komplikasi anemia. Rata-rata ketahanan hidup pasien dengan komplikasi anemia adalah 66,50 bulan, sedangkan yang tidak sebesar 68,75 bulan. Berikut dijelaskan pada gambar 10.

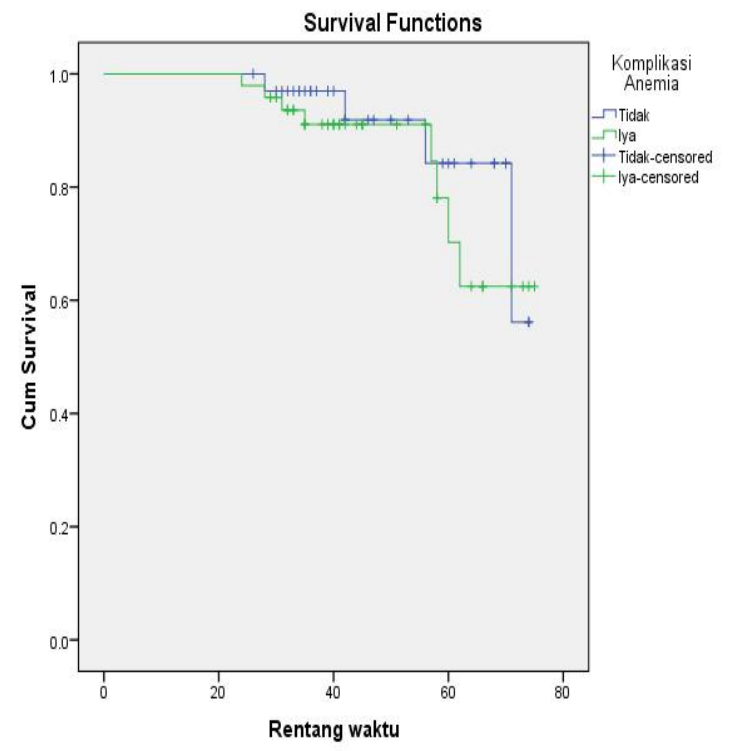

Gambar 10. Kurva survival pasien berdasarkan komplikasi anemia.

\section{PEMBAHASAN}

Berdasarkan hasil penelitian terdapat 82 data pasien PGK yang mulai menjalani Hemodialisis pada periode 2010-2013. Dari 82 data pasien tersebut, rata-rata pasien berusia 44 tahun. Laporan dari Yayasan Ginjal Diatrans Indonesia (YGDI) pada tahun 2006, sebanyak 49\% penderita PGK adalah usia 35-55 tahun. Meningkatnya usia seseorang memberikan dampak pada penurunan fungsi-fungsi tubuh sehingga semakin rentan terhadap penyakit. Umur pasien yang meningkat juga berkaitan dengan prognosis suatu penyakit dan harapan hidup ${ }^{8}$.

Ketahanan hidup pasien dengan usia 46-65 tahun lebih rendah diperkuat dengan penelitian oleh Valdivia dkk ditahun 2013. Menurut Valdivia dkk, ketahanan hidup pasien PGK yang menjalani HD untuk usia $>60$ tahun adalah $0 \%{ }^{9}$. Itu artinya ketahanan hidup pasien dengan usia tua sangat rendah. Semakin bertambahnya usia, semakin berkurang fungsi ginjal dan berhubungan dengan penurunan kecepatan ekskresi glomerulus dan memburuknya fungsi tubulus $^{10}$. Adanya perbedaan yang signifikan juga diperkuat dengan penelitian oleh Rolim, dkk (2014) yang menyatakn bahwa terdapat perbedaan pada kurvasurvival pasien PGK dengan 
Hemodialisis yang berusia $<60$ tahun dan $>60$ tahun.

Pasien dengan jenis kelamin lakilaki jumlahnya lebih banyak jika dibandingkan dengan pasien perempuan. Kecenderungan jumlah pasien laki-laki lebih banyak dibandingkan dengan perempuan dikarenakan faktor pekerjaan pada laki-laki lebih berat baik dari segi beban fisik maupun beban mental yang dialaminya dan faktor gaya hidup seperti merokok dan konsumsi junk food ${ }^{1}$. Menurut penelitian oleh Benedict, dkk (2003), salah satu perilaku yang memiliki resiko serius terhadap kesehatan adalah merokok. Perilaku merokok dapat menyebabkan seseorang beresiko menderita gagal ginjal kronik 2,2 kali lebih tinggi dibandingkan dengan individu yang tidak merokok. Namun pada angka ketahanan hidup, pasien laki-laki lebih bisa "survive" daripada pasien perempuan. Hal tersebut diduga pengaruh dari lemahnya fisik perempuan dibandingkan dengan laki-laki.

Tidak signifikannya perbedaan yang ada pada karakteristik jenis kelamin ini sama halnya dengan penelitian oleh Rolim, dkk (2014). Penelitian tersebut menjelaskan bahwa tidak ada pengaruh jenis kelamin terhadap ketahanan hidup pasien PGK yang menjalani Hemodialisis.

Banyaknya pasien yang memiliki riwayat Hipertensi sesuai dengan beberapa pernyataan baik dari jurnal maupun sumber data lain. Berdasarkan USRDS 2014, persentase penyakit Hipertensi menjadi nomor dua tertinggi setelah DM pada etiologi penyebab PGK. Angka ketahanan hidupnya juga lebih rendah jika dibandingkan dengan pasien yang tidak memiliki riwayat penyakit Hipertensi. Hal ini dikarenakan Hipertensi yang lama menyebabkan nefrosklerosis dan semakin lama menderita Hipertensi, maka kerusakan glomerulus dan atrofi tubulus semakin parah sehingga menyebabkan seluruh nefron rusak dan berdampak pada gagal ginjal. Selain itu Hipertensi juga merupakan penyebab utama penyakit jantung, di mana penyakit jantung merupakan salah satu penyebab kematian utama pasien $\mathrm{PGK}^{15}$. Maka dari itu, terdapat peran penting Hipertensi mempengaruhi penurunan survival rate pasien PGK yang menjalani Hemodialisis.

Meskipun jumlah pasien dengan riwayat DM lebih sedikit dibandingkan dengan yang tidak ada riwayat DM, namun rata-rata ketahanan hidupnya justru lebih rendah. Perbedaannya juga signifikan. Menurut Valdivia, dkk (2013), pasien dengan riwayat DM pada saat pertama kali melakukan HD memiliki ketahanan hidup 0\% pada tahun ke 5 dan terlihat perbedaan yang signifikan antara pasien DM dan tidak $\mathrm{DM}^{9}$. Hal ini disebabkan oleh DM yang lama akan menimbulkan kerusakan 
pada glomerulus yang ditandai dengan penurunan GFR dan peningkatan kadar kreatinin serta berakhir pada gagal ginjal terminal. Maka dari itu, pasien PGK dengan DM memiliki resiko lebih tinggi ketahanan hidupnya menurun.

Sebagian besar pasien PGK yang menjalani Hemodialisis di RSUD Dr. Soetomo Surabaya menjalani terapi sesuai dengan anjuran yang berlaku. Hemodialisis reguler dikatakan cukup apabila dilakukan teratur, berkesinambungan selama 9-12 jam setiap minggu atau 2 kali tiap minggu.

Ketahanan hidup pasien dengan frekuensi $\leq 2$ kali tiap minggunya lebih tinggi dibandingkan dengan frekuensi $\geq 3$ kali tiap minggu. Hasil ini cukup bertentangan dengan dengan beberapa penelitian yang menyatakan bahwa ketahanan hidup lebih rendah justru pada pasien yang tidak melakukan HD dengan rutin sesuai anjuran yakni kurang dari 9-12 jam perminggunya. Hal ini diduga disebabkan oleh perubahan frekuensi yang penyebabnya adalah adanya komplikasi atau semakin parahnya penyakit ginjal kronis yang diderita pasien. Sehingga terdapat faktor lain yang menyebabkan ketahanan hidup pasien dengan frekuensi $\geq$ 3 kali perminggu menjadi lebih rendah.

Berdasarkan hasil penelitian, pasien dengan komplikasi anemia jumlahnya lebih banyak. Hal ini juga didukung dengan hasil penelitian lainnya yakni menurut Zadeh, dkk (2012) komplikasi yang sering terjadi pada penderita gagal ginjal kronik adalah anemia. Anemia juga hampir selalu ditemukan pada penderita gagal ginjal kronis (80-95\%), kecuali pada penderita gagal ginjal kronis karena ginjal polikistik.

Angka ketahanan hidup pasien PGK yang menjalani Hemodialisis dan memiliki komplikasi anemia lebih rendah daripada yang tidak. Hal ini juga didukung oleh beberapa penelitian lain salah satunya adalah penelitian oleh Valdivia dkk (2013) yang menyatakan bahwa pasien dengan anemia memiliki ketahanan hidup yang menurun seiring dengan bertambahnya tahun. Hasil penelitian tersebut juga menyatakan tidak ada perbedaan signifikan antara anemia dan tidak anemia pada ketahanan hidup pasien. Sama halnya dengan hasil penelitian ini.

\section{SIMPULAN DAN SARAN}

\section{Simpulan}

Berdasarkan hasil penelitian, dapat ditarik kesimpulan sebagai berikut:

1. Jumlah data pasien yang mulai menjalani Hemodialisis periode 20102013 di RSUD Dr. Soetomo Surabaya adalah 82 pasien.

2. Sebagian besar berjenis kelamin lakilaki, rata-rata usia 44 tahun, frekuensi $\mathrm{HD} \leq 2$ kali tiap minggu, memiliki riwayat Hipertensi, Diabetes Melitus dan adanya komplikasi anemia.

3. Rata-rata ketahanan hidup secara umum selama 67,84 bulan. 
4. Karakteristik usia pasien, riwayat Hipertensi dan Diabetes Melitus memiliki perbedaan yang signifikan pada kategorinya masing-masing.

5. Ketahanan hidup pasien usia 46-65 tahun lebih rendah daripada pasien usia 26-45 tahun. Ketahanan hidup pasien dengan riwayat Hipertensi dan Diabetes Melitus lebih rendah daripada pasien yang tidak memiliki riwayat penyakit tersebut.

\section{Saran}

1. Untuk meminimalisir adanya data tersensor, maka sebaiknya memperpanjang periode data yang diambil.

2. Untuk melihat pengaruh antar variabel, tidak dapat menggunakan uji Kaplan Meier maupun uji Log Rank. Uji Cox Regression merupakan uji yang valid dan cocok untuk melihat adanya pengaruh antar variabel ketahanan hidup.

3. Pada penelitian selanjutnya dengan topik yang sama, memungkinkan untuk menggunakan variabel-variabel lain yang lebih dalam guna memperlihatkan tingkat ketahanan hidup yang lebih spesifik karena pada penlitian ini, variabel yang ada hanyalah secara umum dan tanpa ada campur tangan variabel lain yang lebih detail.

4. Dalam bidang ilmu kesehatan masyarakat, saran yang dapat diberikan adalah terkait upaya preventif agar tidak terjadi adanya penyakit PGK. Upaya tersebut seperti perbaikan pada faktor perilaku individu yaitu pola makan, aktivitas fisik, konsumsi obat dan lain-lain. Selain itu, upaya preventif juga dapat dilakukan pemerintah pada pemanfaatan pelayanan kesehatan primer untuk menjadikan pelayanan kesehatan primer tersebut media promosi dan edukasi tentang kesehatan ginjal dan jantung. Sehingga outcome dari upaya tersebut yaitu meningkatkan pengetahuan, perubahan pola perilaku dan kesadaran kesehatan individu tercapai maksimal.

\section{DAFTAR PUSTAKA}

National Kidney Foundation. 2002. K/DOQI Clinical Practice Guidelines for Chronic Kidney Disease: Evaluation, Classification and Stratification. New York: National Kidney Foundation, Inc. Tersedia di: <www.kdoqi.org> [ 19 Maret 2016].

National Kidney Foundation. 2015. US Renal Data System 2014 Annual Data Report: Epidemiology of Kidney Disease in the United States. American Journal of Kidney Disease, 66 (1): pp 31-40. Tersedia di: <www.ajkd.org> [1 April 2016].

Pernefri. 2012. $5^{\text {th }}$ Report of Indonesian Renal Registry. Jakarta: Indonesian Society of Nephrology. Tersedia di: <www.pernefri-inasn.org> [1 April 2016]. 
Sukandar, E. 2006. Gagal Ginjal dan Panduan Terapi Dialisis. Bandung: Universitas Padjajaran.

Sikole, A., Nikolov, V., Dzekova, P., Stojcev N., Amitov V., Selim G., Asani A., Gelev S., Grozdanovski R., Masin G., Klinkmann H \& Polenakovic M. 2007. Survival of Patients of Maintenance Haemodialysis Over a Twenty Year Period. Prilozi, Odd. Boil Med Nauki, 28(2).

Wingard, R.L., Chan, K.E., Lazarus, M \& Raymond M. 2009. The "Right" of Passage: Surviving the First Year of Dialysis. Clinical Journal of The American Society of Nephrology, 4.

Collect, D. 1994. Modelling Survival Data in Medical Research. Chapman and Hall. London.

Putri, R., Sembiring, P.L., \& Bebasari, E. 2014. Gambaran Kualitas Hidup Pasien Gagal Ginjal Kronik yang Menjalani Terapi Continuous Ambulatory Peritonial Dialysis di RSUD Arifin Achmad Provinsi Riau dengan Menggunakan Kuisioner KDQOL-SF. Skripsi. Universitas Riau.

Valdivia, J., Gutierrez C., Treto J., Delgado E., Mendez D., Fernandez I., Abdo A., Perez L., Forte M \& Rodriguez Y. 2013. Prognostic Factors in Hemodialysis Patients: Experience of a Havana Hospital. MEDICC Review, 15(3).

Pranandari, R.\& Supadmi, W. 2015. Faktor Risiko Gagal Ginjal Kronik di Unit Hemodialisis RSUD Wates Kulon Progo. Majalah Farmaseutik, 11(2). Universitas Ahmad Dahlan.
Benedict, S., Michele E T., Neil R P., Mark S E., \& Frederick L B. 2003. Lifestyle Factors, Obesity and The Risk of Chronic Kidney Disease. Epidemiology, 14(4). Tersedia di: <http://www.jstor.org> [16 Juni 2016].

Shankar, A., Klein, R., \& Barbara. 2006. The Association Among Smoking, Heavy Drinking and Chronic Kidney Disease. American Journal of Epidemiology, 164(3). Tersedia di: <http://aje.oxfordjournals.org> [16 Juni 2016].

Rolim, F.I., Maria LHL., Giselle A. \& Ricardo FS. 2014. Survival of Hemodialysis Patients at A University Hospital. J Bras Nefrol 2015, 37(1): 64-71. Brazil: University of Maranhao (UFMA).

Budiyanto, C. 2009. Hubungan Hipertensi dan Diabetes Melitus Terhadap Gagal Ginjal Kronis. Kedokteran Islam 2009.

Echder, T., \& Schriner, R.W. 2009. Cardiovascular Abnormalities in Autosomal-Dominant Polysystic Kidney Disease. Nat Rev Nephrol, 5(4): pp 221-228.

Rully, R \& Abdul, H. 2000. Hypertension, Microalbuminuria, and Diabetic of Nephropathy. $13^{\text {th }} \quad$ Asian Colloquium in Nephrology. Bali: The Indonesian Society of Nephrology.

Mousavie, B., Hayati, F., Ansari, M.J.A., et al. 2010. Survival of Diabetes Patients on Hemodialysis. Iranian Journal of Kidney Disease, 4 (1): pp 74. 